\title{
Haitian Archaeological Heritage: Understanding Its Loss and Paths to Future Preservation
}

\author{
Joseph Sony Jean ${ }^{1, *(\mathbb{D}}$, Marc Joseph ${ }^{2}$, Camille Louis ${ }^{2}$ and Jerry Michel ${ }^{3,4}$ \\ 1 Royal Netherlands Institute of Southeast Asian and Caribbean Studies, Reuvensplaats 2, \\ 2311 BE Leiden, The Netherlands \\ 2 Department of Anthropology, University California Santa Cruz, 1156 High St, Santa Cruz, CA 95064, USA; \\ majoseph@ucsc.edu (M.J.); clouis1@ucsc.edu (C.L.) \\ 3 Department of Sociology, Université d'Etat d'Haïti, 21, rue Rivière, Port-au-Prince HT6112, Haiti; \\ mycoje@yahoo.fr \\ 4 Department of Sociology, Université Paris 8, 2 rue de la Liberté, Saint-Denis 93526 Paris, France \\ * Correspondence: jean@kitlv.nl
}

Received: 14 June 2020; Accepted: 7 July 2020; Published: 11 July 2020

\begin{abstract}
Haitian archaeological heritage is expressed through multiple traces of Amerindian cultures, enslaved African legacies, ruins of old colonial plantations and fortresses, and post-Haitian independence. Despite the existence of legal institutions engaged in the protection of this heritage, Haitian archaeological sites are becoming more threatened because of looting, appropriation of spaces, and lands management, as well as natural hazards. This paper aims to explore the current state of archaeological heritage with the broader context of the politics of heritage in Haiti. We analyzed the conditions of archaeological sites from the northern region and addressed their place in official heritage practices. The results of this study revealed that most of the archaeological sites that reflect the complexity of Haitian history are not given much attention in the politics of heritage that prioritize the nationalistic and emblematic character of historic traces. This study highlighted the importance of a new approach that prioritizes multiple voices to address heritage matters for the future.
\end{abstract}

Keywords: archaeological heritage; public institutions; heritage politics; heritage management; Haiti

\section{Introduction}

Cultural heritage includes all property, whether material or non-material, that has a historical and artistic character and belongs to a country, region, city, or to social groups or individuals. Moving from a utilitarian vision to a dynamic of participatory construction [1-5], heritage becomes the historical, cultural, and social wealth associated with the territory whose identity it bears in various forms [6,7]. Heritage "encompasses a range of things from large to small, grandiose to humble, natural to constructed ... everything from whole landscapes to tiny fragments of bone, stone, charcoal in archaeological sites" [3] (p. 5). The problematic polysemy of the term does not, however, obscure its historical and cultural significance, which must be transmitted from one generation to the next $[3,8]$. According to Pajard and Olivier, heritage might be considered a trace of the past in various respects; it has the particularity of having to be legitimated, of being a sign-representation, or even a sign-symbol of a collective identity around a territory, a culture or a group [9] (p. 374). In this sense, Haiti's heritage bears witness to the richness of the works and traditions stemming from its history. Various populations, including Amerindian, European, African, and Asian, have lived and succeeded one another through the centuries; all have put their mark on the landscape via the caves, colonial dwellings, fortifications, churches, palaces, houses, natural sites, and traditions and cultural practices around which the nation's heritage, cultural identities and collective memory have been shaped. 
Haiti contains a large number of archaeological heritage sites that reflect this diverse history of cultural development in the islands. Caribbean archaeological heritage is facing important political, economic, and ecological problems, as well as the fast development of tourism [10-12]. Scholars address the challenges of protecting cultural heritage sites by focusing on laws and regulations [13]. The Caribbean's exposure to natural disasters (climate change, sea-level rise, hurricanes, earthquakes, and volcanic eruptions) make its cultural heritage more and more vulnerable [10,12-25]. Haiti's archaeological heritage is among the most threatened in the region due to the country's many chronic political, economic, and environmental problems [26-29]. Despite the existence of laws and regulations, destruction and looting of archaeological sites, as well as investigations without government permits or controls, have dealt a major blow to the future of Haiti's remaining archaeological heritage. In addition, the importance of this nation's archaeological heritage has not been widely promoted in the public arena.

Safeguarding the future of this archaeological heritage calls for a strong management vision and plan, even as human factors and natural disasters affect that heritage and often result in its transformation and loss [30]. The preservation of a heritage site depends on many factors. Geographical, societal, economic, and political aspects can determine its loss or protection, depending on the type of governance involved. In some instances, in the context of internal and global economic crises, institutional authorities prioritize struggles to redress basic economic challenges at the expense of putting effective strategies in place to protect heritage [31], even though archaeological tourism based on specific archaeological sites can often enhance economic activities at local and national levels [32-34]. With no effective policy to protect archaeological sites, the economic value that encourages a tourist economy is likely to cause damage, depriving future generations of that heritage. The value-based approach to heritage developed by the International Council on Monuments and Sites [35] has been criticized, since:

"A values-based approach, though supposedly placing people at the core of conservation and management (through the concept of stakeholder groups), actually tends to promote community involvement within conservation professionals' rules and under their supervision. The concept of stakeholder groups, as defined and applied in a values-based approach, is rather problematic, obtaining meaning and existence through conservation professionals' power" [36] (p. 174).

This approach is then related to the power of conservation professionals focusing more attention on the tangible rather than the intangible aspect of archaeological heritage. Ioanis Poulios $[36,37]$ proposes instead that a "living heritage approach" be used in parallel with a value-based approach, because it "is inextricably linked to a specific community that retains its original association with it throughout time (continuity), by maintaining its function and continuing the process of its spatial definition and arrangement over the course of time to the present" [36] (p. 175). This approach considers the core community as inseparable from a site [38-42]. In this sense, heritage practices "can take an active engagement with communities expressing contemporary concerns for social change" [43] (p. 201) and for retelling and communicating the community's history [44,45]. Considering a broad scenario that includes various archaeological sites and objects, this approach also requires taking into account multiple types of archaeological resources, especially when all are faced with a lack of policy related to their safeguarding from loss to the anticipation of their future. The role of institutions such as museums should also be considered in the process of protecting mobile cultural heritage (e.g., artifacts) and making it available to various interested publics for purposes of education, history, memory, and scientific knowledge. Marie-Lucie Vendryes [46] (p. 48) points out that the opposite is true in the Haitian context, because "the number of public institutions safeguarding the country's memory is a marker for what must be termed a failure in terms of preservation and transmission of movable cultural goods." The role of archaeological heritage in a post-colonial context like Haiti is also fundamental to questioning biased colonial historical narratives, as it is able to offer an alternative discourse on a common past, even though heritage is often "subject to contestation and malleable to the needs of societies and cultures in the present" [47] (p. 50). 
Haitian archaeological heritage is being irreparably damaged in the absence of protective mechanisms that can ensure its longevity $[48,49]$. The current state of heritage practice calls for a critical prism through which to examine the politics of heritage, the processes of preservation, management, and appropriation, and the future of the Haitian archaeological heritage. Kenrick Demesvar [50] argues that local communities should be encouraged to get involved in the management of heritage sites (Parc Historique National), while seeking economic development that is compatible with the conservation of heritage resources and the local, regional, and national economy, through recreation and tourism. Geller and Marcelin [51] found that in Haiti, when vernacular culture shares common ground with official interests in the preservation of a World Heritage site, this situation can create opportunities for collaboration among local communities, national institutions, and international organizations in the management of the site. Scholars must also take on board the intangible dimension of Haitian cultural heritage in a touristic context [52,53], by considering community participation in touristic development [54], through religious identity construction [55], and patrimonialization of slavery [56]. The goal of this paper is to challenge current tendencies in Haitian heritage activities that prioritize the protection of certain types of archaeological heritage while the majority of archaeological sites and other cultural materials are lost. Preserving a broader range of the ephemeral material traces of Haiti's deep and diverse historical past is not currently high on any national political or cultural agenda, despite regulations that place them in the public domain. This paper outlines the current state of Haitian archaeological heritage, drawing on the role of public institutions in the protection of heritage and addressing discussions on the place of archaeological resources with regard to heritage management and practices more broadly.

\section{Background: Archaeological Research in Haiti}

Knowledge of the Haitian past that is based on archaeological research has come through a long process of collecting artifacts and investigating sites. In the 18th century, the French historian Charlevoix [57] identified Amerindian iconographies and objects in the colony of Saint-Domingue. André Delpuech [58] noted this as the first observation with an archaeological character, which created the basis for French scientists of the colony to establish early archaeological work in Saint-Domingue. Moreau de Saint-Merry reported that "the remains of tools used by the natives who inhabited the region were found throughout the town of Limonade" [59] (p. 206). Amerindian objects collected in the colony of Saint-Domingue were sent back to France to be exhibited in Cabinets de Curiosités during the 18th century. Some of the collected objects were used to set up an Indian museum at Cap-Francois [58]. These objects were important in implementing colonial discourse and legitimating the scientific views of members of the Cercle des Philadelphes.

During the late 19th and first two decades of the 20th century, in the context of Haitian post-independence, attention was paid to Amerindian agricultural practices, plant uses, and prehistoric objects found in Haiti [60-64]. In the region of Fort-Liberté, during the American occupation of Haiti (1915-1934), the Pettigrew family surveyed and collected artifacts [65]. As the result of these efforts archaeological investigations became more important and Herbert Krieger investigated many archaeological sites in the Fort-Liberté region, Port-au-Prince Bay, the Cul de Sac, the Plaine de Leogane, Hinche, and the Massif du Nord. Godfrey Olsen and Harrison K. Bird investigated archaeological sites in the south of Haiti during the same period [66,67]. Some years later, Haiti received more attention during early West Indian archaeological investigations, through the presence of American archaeologists such as Froehlich Rainey, Irving Rouse, and Stanley Boggs [68-71].

Scientific research continued in parallel with collecting and conserving Amerindian objects. A large proportion of these objects were part of a National Museum founded by President Stenio Vincent in 1938 [72,73]. Archaeological research in Haiti continued hand-in-hand with the founding of the Bureau Ethnologie in 1941, a public institution created to renew interest in pre-Columbian archaeology and ethnography. Jacques Roumain, as director, led this new institution to organize, for the first time, an archaeological congress (Congrès Régional d'Archéologie Préhistorique). This event 
can be considered the starting point of Haitian scholars promoting Amerindian cultures, which, for a long time, had been stereotyped and dismissed in intellectual debates [72]. However, under the Bureau Ethnologie's authority, archaeological investigations were undertaken over several years, with the objective of promoting Amerindian history and culture in society [74-81]. These investigations reinforced the museum collections with pre-Columbian archaeological objects. Less archaeological work took place in Haiti during the 1970s; however, the arrival of the Hodges family in northern Haiti boosted archaeological research at that time [82-84]. A significant portion of Haiti's archaeological heritage is still conserved and exhibited at the Guahaba Museum at Limbé town; a private museum built by this family in 1983. Other archaeological works highlighted the culture history of the native Amerindian cultures in Haiti [85-90]. Some were based on documenting Amerindian settlement dynamics on national and regional scales [26-29]. It is also important to note that many archaeological caves including some with rock art as well as riverbed petroglyph sites have been documented in Haiti [91-97].

In contrast with the role of archaeology in documenting the pre-colonial cultural history of the native Amerindian peoples of the island, Haiti's colonial history is mostly based on written sources. Archaeological knowledge related to the colonial period is rarely used to challenge data in the colonial archives and historical narratives. For instance, the archaeology of early European colonization was undertaken on a small scale, with a specific focus on the Spanish settlement at En Bas Saline and Puerto Real. This project was conducted mainly by American-trained researchers from the University of Florida (1979-2004) and is notable for introducing a multidisciplinary approach that involved the integration of history and archaeology in Haiti [98-108]. These works contributed to our understanding of the early stages of European colonization in Haiti, especially daily life in the Spanish colonial town of Puerto Real. Despite the role of Saint-Domingue in the process of shaping the history of the global colonial system, archaeology related to the French colonial period in Haiti is grossly underdeveloped compared to that of the rest of the Caribbean. This situation means that archaeological data are nearly absent from Haitian colonial history. As a result, there are serious gaps in our understanding of European colonial history in Haiti, which need to be further addressed.

The long-term work of surveying, cataloguing, and mapping the ruins of plantations and colonial and national forts by the Institut de Sauvegarde du Patrimoine National (ISPAN) [109] also requires other scales of analysis. Archaeological remains have only now begun to impact how we analyze colonial history in Haiti $[27,110,111]$. On a larger scale, archaeological work on colonial plantations has recently been used to highlight the historical development of northern Haiti, by focusing on the Fort-Liberté region [27]. By mapping different features of the colonial settlement, this work helps to capture the strategies used by the French colonists to organize the landscape, to control the lands and people, and to put in place defensive strategies through the distribution of many colonial forts [27]. The Milot Archaeology Project involves studying the historical transformation of the Milot's historical landscape by exploring the lifeways of the Kingdom of Henry Christophe in northern Haiti after the Haitian Revolution [112].

Overall, these projects contribute to an understanding of Haitian archaeological heritage, although a large part of the archaeological materials collected during these investigations is currently housed in the United States by the museums affiliated to institutions that conducted the research. However, they are not easily accessible to local researchers and students in the process of gaining knowledge of the past.

\section{Note on Method}

This paper uses northern Haiti's case as an example that is applicable to the rest of the country. Northern Haiti contains an impressive number of archaeological sites comprising caves, cave shelters, and open-air Amerindian, colonial, and post-independence archaeological sites that are currently at risk for many reasons, from natural disasters to human interventions. The main objective of this article is to give a regional overview of the current state of the archaeological heritage by focusing on the role 
of public institutions in safeguarding these resources for society. For many years, researchers have undertaken regional archaeological surveys in northern Haiti to capture Amerindian settlement patterns and have recorded around 300 archaeological sites [27-29]. The last regional archaeological survey focused mainly on understating the long-term landscape transformation of the Fort-Liberté region [27]. Many places related to Amerindian and colonial settlements have been recorded and revisited. These efforts provide an essential update of our understanding of the long-term historical development of the region. This article uses Fort-Liberté's case and three sectors in the North, which comprise En Bas Saline, Puerto Real, and Milot in the North department, to give a more comprehensive overview of the current conditions of archaeological heritage in Haiti (Figure 1). It is particularly important to select these locations to discuss the place of different types of archaeological sites in the heritage management in Haiti regarding the role of public institutions in protecting archaeological heritage.

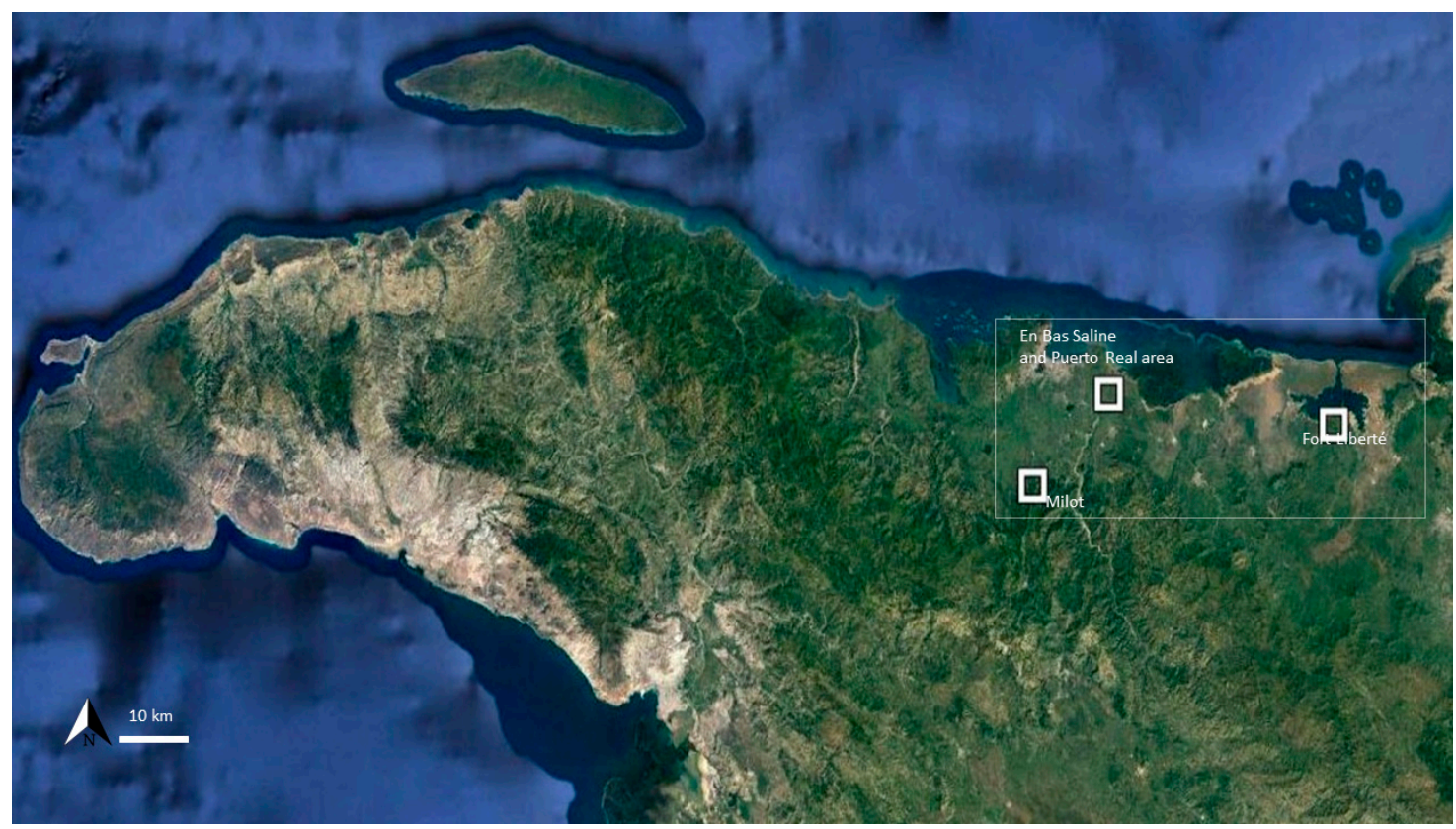

Figure 1. Map of northern Haiti modified from Google earth, showing the location of the case studies.

\section{Current State of Archaeological Heritage: Northern Haiti}

\subsection{Fort-Liberté Region}

An archaeological and ethnographic survey of living heritage was conducted in the area of Fort-Liberté during 2014-2016, that identified a large number of threatened archaeological sites [27,113]. Individuals living around the Fort-Liberté region expressed concern about the absence of engagement by public authorities in the protection of archaeological heritage in the region [113]. There is clearly a lack of official heritage awareness, leading to escalating heritage loss. Houses are often built and modern villages expanded on archaeological sites in this area (Figure 2). Individuals collect artifacts and sell them to national and international relic collectors. Many sites have been damaged or totally lost due to agricultural activities and road and house construction. The ruins of colonial plantations are often deliberately damaged or destroyed. Colonial-era iron sugar-cooking pots and olive jars, bricks, and rocks from ruins are reused for personal and economic purposes (Figure 3) Some landowners consider archaeological remains as their property and act as they like, and this is used to legitimate the destruction on many sites.

There are no protection plans for archaeological heritage in the context of land management at the national level. Some local administrations do not even have an office dedicated to the inventory and assessment of archaeological heritage. Development projects are a widespread threat to archaeological 
sites and biodiversity, primarily when these particular elements of the cultural landscape are not evaluated. For instance, a sisal plantation was established in the Fort-Liberté region (1926-1987), resulting in extensive exploitation of land and the building of factories and roads. This land use had significant impacts on both Amerindian and colonial sites.

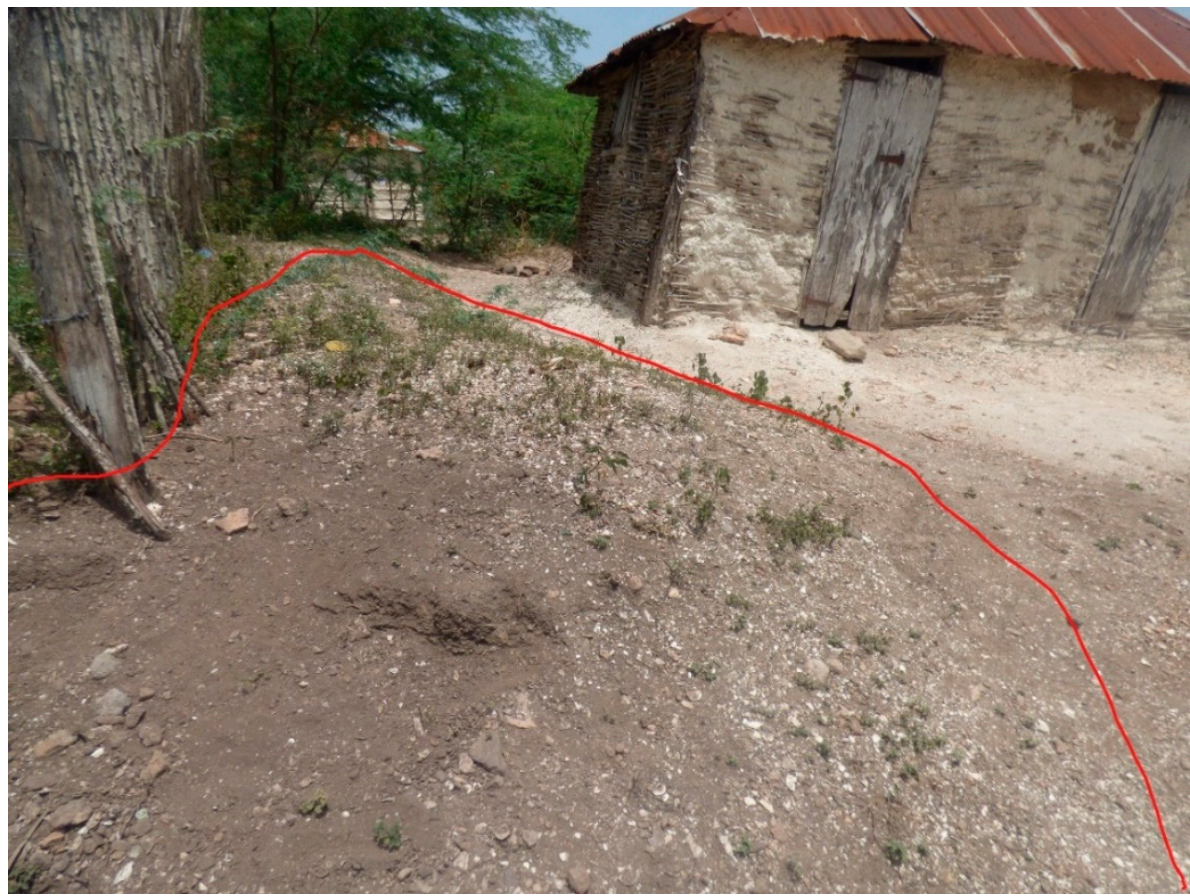

Figure 2. Modern village on an archaeological site. The red graphic shows a mound with ceramic and shell deposits.

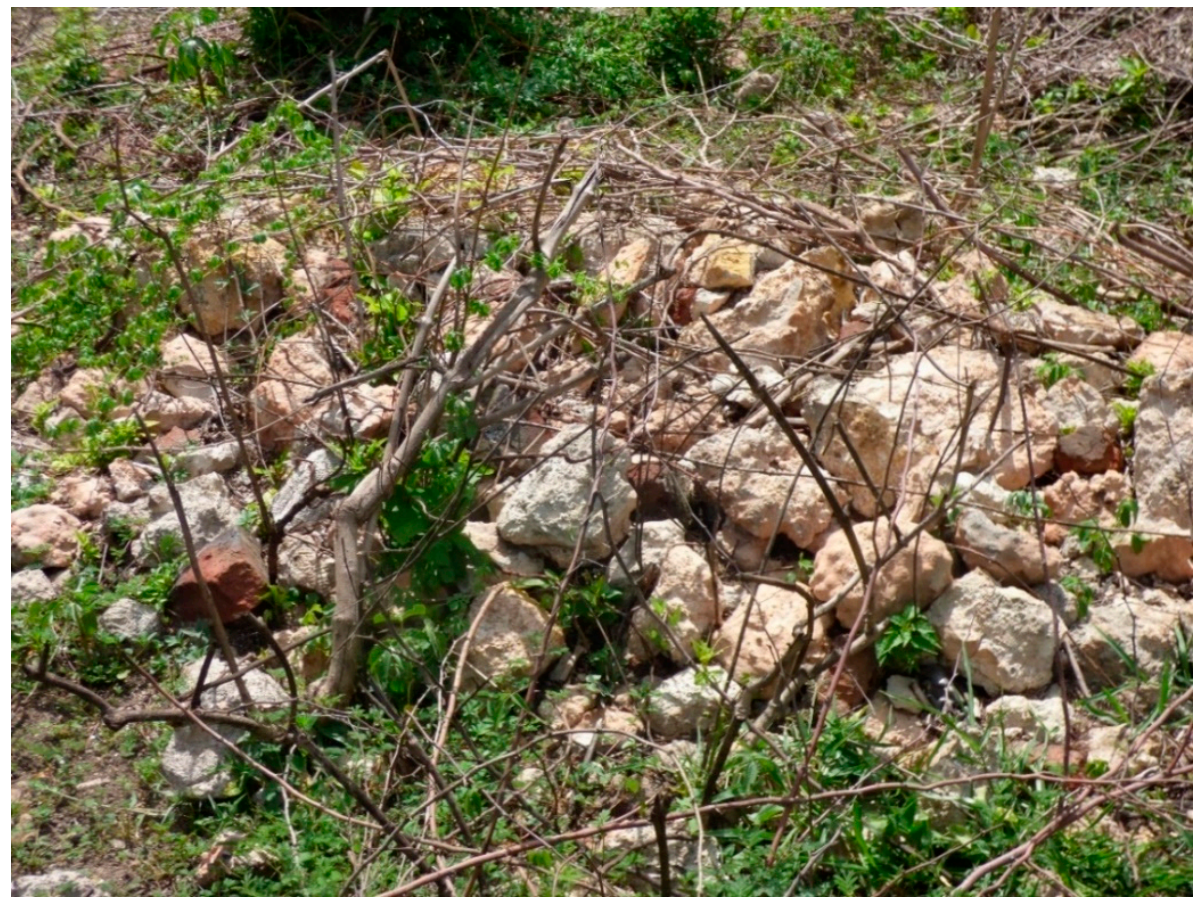

Figure 3. Archaeological remains (rocks and bricks) from a destroyed colonial ruin. They are used for rebuilding modern houses or for other personal purposes. 
Archaeological remains collected by American researchers during the establishment of sisal plantations are housed in museums in the USA. A new sisal plantation pilot project has started recently in the same region, on 4000 ha, which will have potential consequences for cultural heritage. The Environmental Impact Assessment, SISALCO 4.000 ha Pilot Sisal Plantation Project in North-East Haiti report made for the Minister of Agriculture detailed "relevant national institutions" that are involved in the project [114] (p. 136). The heritage institutions, as guardians of Haitian archaeological heritage, were not taken into account regarding directives and guidelines for respecting archaeological heritage in this context of land use and management. The document lists the institutional conventions and treaties as instruments of the international legal framework that Haiti has recognized, by pointing out that "Haiti has a legal framework for human lives and environment protection." However, Haiti acknowledged other international conventions, for instance, on cultural heritage, none of which was noticed in the assessment.

Another assessment for the Ministry of Agriculture, Etude d' impact social du projet proposé de développement du Sisal dans la région Nord-Est d'Haïti, has vaguely recommended that "where necessary, the discovery of archaeological or physical cultural materials during land development should be reported and monitored by the Haitian authorities, preferably with the participation of ISPAN and the local university" [115]. Regional cultural heritage, which has already been evaluated [28,29,116], was not taken into account in the project. In addition to human factors, environmental issues have resulted in the deterioration of archaeological heritage along the coastline. For instance, Figure 4 shows an Amerindian site and an old colonial site that have been damaged by marine erosion.
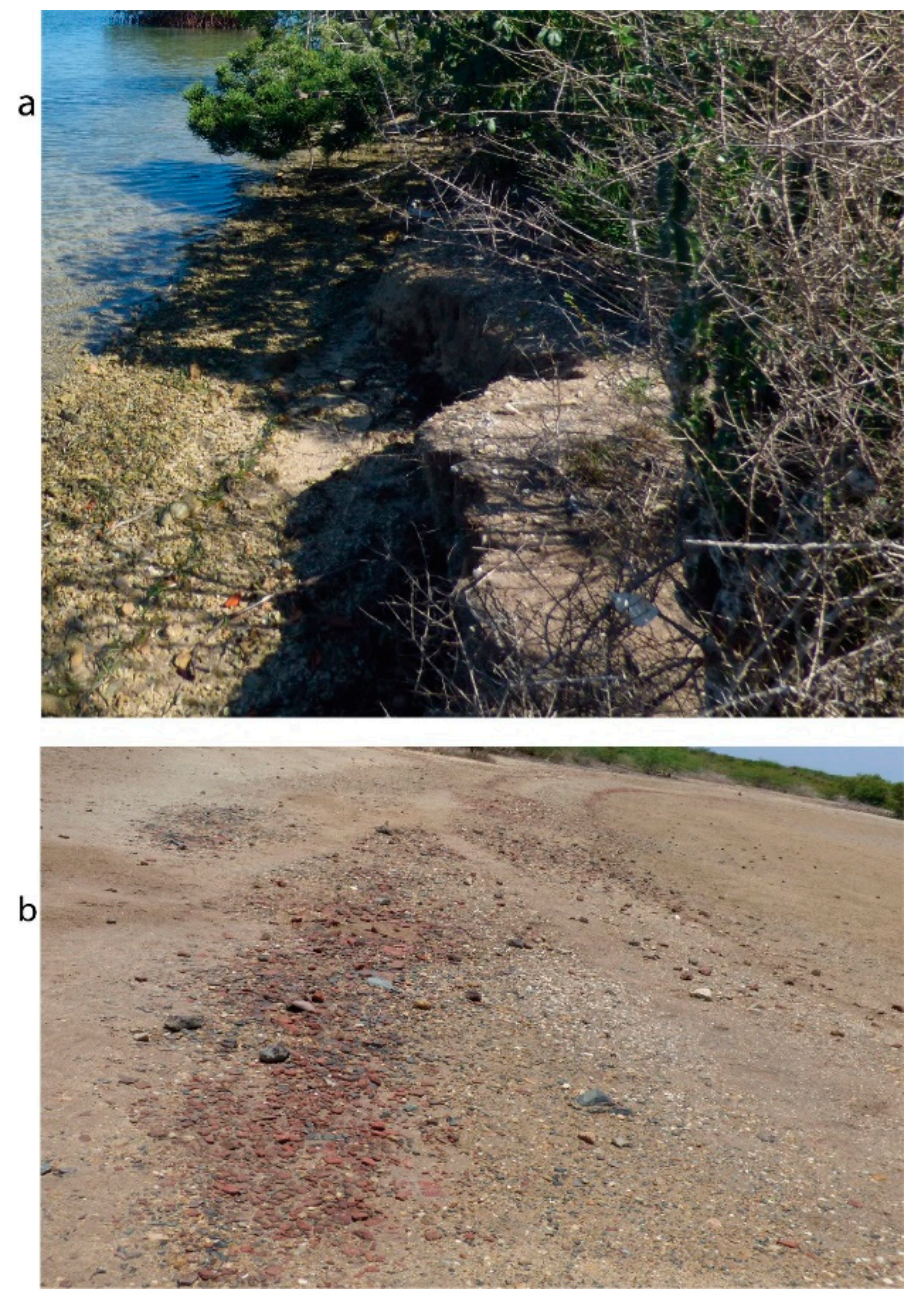

Figure 4. (a) Amerindian site; (b) Colonial site, both damaged by tidal action. 


\subsection{Puerto Real and En Bas Saline}

Damage to archaeological sites has occurred on a large scale, which can be seen in any part of Haiti. Some well-known sites have been forgotten or destroyed due to the absence of any particular focus that could activate their protection and valorization. Sites at both En Bas Saline and Puerto Real have been intensively excavated by researchers from the University of Florida. This project was supported by the Organization of American States (OAS), recognizing Puerto Real's potential universal value to understanding global history [48] (p. 183). The overall research sheds light on the human activities that took place throughout the Spanish occupation. These sites are nowadays severely endangered and forgotten, like other threatened sites in the country.

The first colonial fort in the Americas, La Navidad was built from the remains of the Santa Maria by Christopher Columbus in the En Bas Saline sector in 1492, but found in ruins during his return in 1493. Researchers believe that En Bas Saline is the main Taino village of the Indian chief Guacanagari who assisted Christopher Columbus. Despite previous large-scale investigations, a big part of the En Bas Saline site has still not been investigated, and there could be enormous advantage in discovering important untold stories, which could add to current knowledge about the life of the indigenous populations and the early European colonization in Haiti. En Bas Saline is currently under settlement pressure, creating impacts characterized by looting, the expansion of houses and agricultural activities (Figure 5). Despite the importance of the site in the process of understanding the interactions between the Indigenous societies and African and European colonists, there is no management plan to protect the investigated and non-excavated parts.

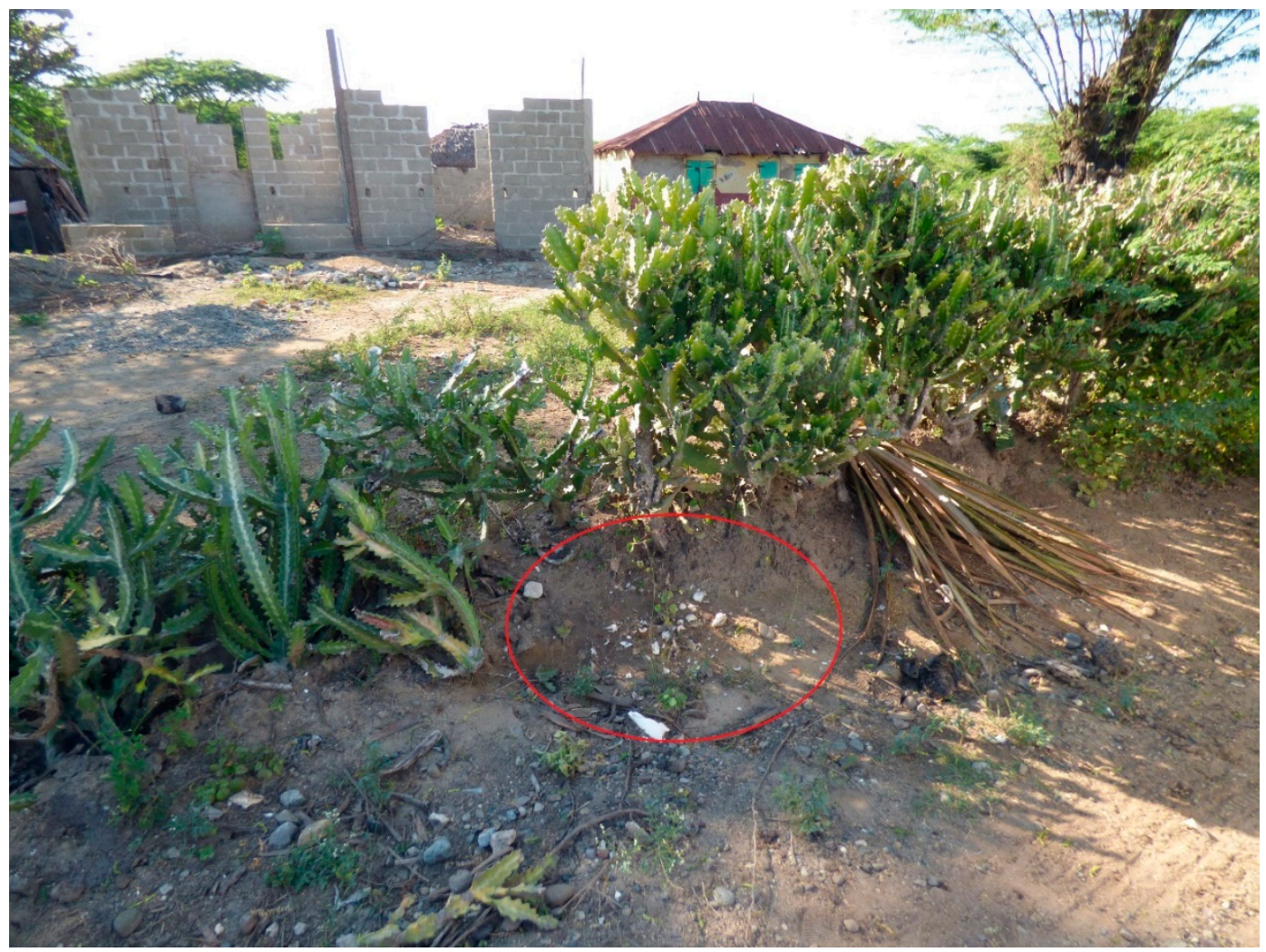

Figure 5. Extension of modern village on En Bas Saline site. In the red circle, a layer of archaeological shell deposits.

The case of Puerto Real is similar to En Bas Saline's condition as a neglected place. Puerto Real was the earliest historic Spanish town built in Haiti in 1503 and situated around $2 \mathrm{~km}$ from the En Bas Saline site. The Puerto Real site is now a large farm located on a private enclosed property that 
has been recently assessed for its touristic values (Rapport d'inventaire des ressources touristiques d' Haiti 2013) [117]. Rachel Beauvoir-Dominique has suggested that the site is of national, Caribbean, and international value $[48,118]$. Traces of an irrigation canal serving the French colonial plantation and some sparse, broken bricks can be identified on the site. A multidisciplinary research program demonstrated important interactions between Amerindians, Africans, and Europeans that shaped the multi-ethnic dynamic of the town, where Africans and Amerindians occupied a lower position in the social, political, and economic hierarchy due to their unfree status in the town. This colonial urban settlement comprised linear features shaping a rectangular form, the evidence of the main Spanish urban colonial patterns. This plan combined religious and governmental components organized in the central plaza, residential houses, and production activities according to the status of different social groups [108]. Puerto Real is historically significant in general Haitian history because it reflects the beginning of the colonial transformations in Haiti and is one of the earliest places in which the "New World" Spanish colonial system was implemented as an experiment [108].

\subsection{World Heritage Site: Parc National Historique}

Despite its management document plan, the Parc National Historique, classified as a World Heritage Site in 1982, has suffered a great deal of damage, and this could lead to serious threats to its integrity [50,119]. The park consists of the Citadelle la Ferrière; the Ramiers complex; and the Sans-Souci Palace and its dependent components, comprising the Chapelle Royale de l'Immaculée Conception, which is a universal symbol of freedom and victory over slavery, built after the 1804 Revolution and an excellent archaeological feature. Since the 1842 Cap-Haitien earthquake damaged the site, humans have further contributed to its slow deterioration. In earlier times, the Sans-Souci Palace was subject to looting by the inhabitants of the area who came to remove stones, bricks, and iron for the construction of their houses. It was reduced to a complex for grazing herds of goats. A recent fire completely destroyed the dome of the royal chapel at Milot-one of the first buildings, built between 1810 and 1813, after Haitian independence-prompting more concern about developmental threats (Figure 6). Although the Citadelle is more protected, due to its location at a high altitude, the Sans-Souci Palace and its surroundings are more exposed to dangerous conditions.

In 1979, the site of Sans-Souci was the subject of archaeological excavation. This excavation allowed ISPAN to administer the site through a maintenance council to gain information on the architecture of the palace, to shore up some walls, and to slow the physical destruction of the complex. Destruction of the palace walls began to slow in 1979, but the history of the palace remained obscure. Only the Citadelle managed to escape serious deterioration. The Citadelle, Ramiers, and the Palace of Sans-Souci sites are part of the landscape of power in the Northern Historical Park, exemplified by the splendor of the Citadelle, a military building with a sense of grandeur, and the centre of Christophe's hegemonic power. Archaeological investigations conducted in 2015 to 2018 shed new light on the long-term occupation of the site and may change the traditional narrative of the place. The historical framework for the evolution of the space, from the Amerindians to the first free Haitians, is beginning to take shape. Milot holds some of the deepest secrets of the area's past. Excavations at the palace have revealed an Amerindian occupation and former French colonial ruins. These secrets are now emerging, thanks to archaeological research, surveys, and excavations [112]. Despite having a management plan, the site is still a center for unsustainable social activities, such as a soccer field, a place for meetings, a home for pet animals, and even a rubbish dump. This regional picture, with its specific focus, exemplifies a broader view of the growing risks that archaeological sites in Haiti face today. Other colonial ruins, old cemeteries, and Amerindian and underwater sites are falling into the same trends towards oblivion. 

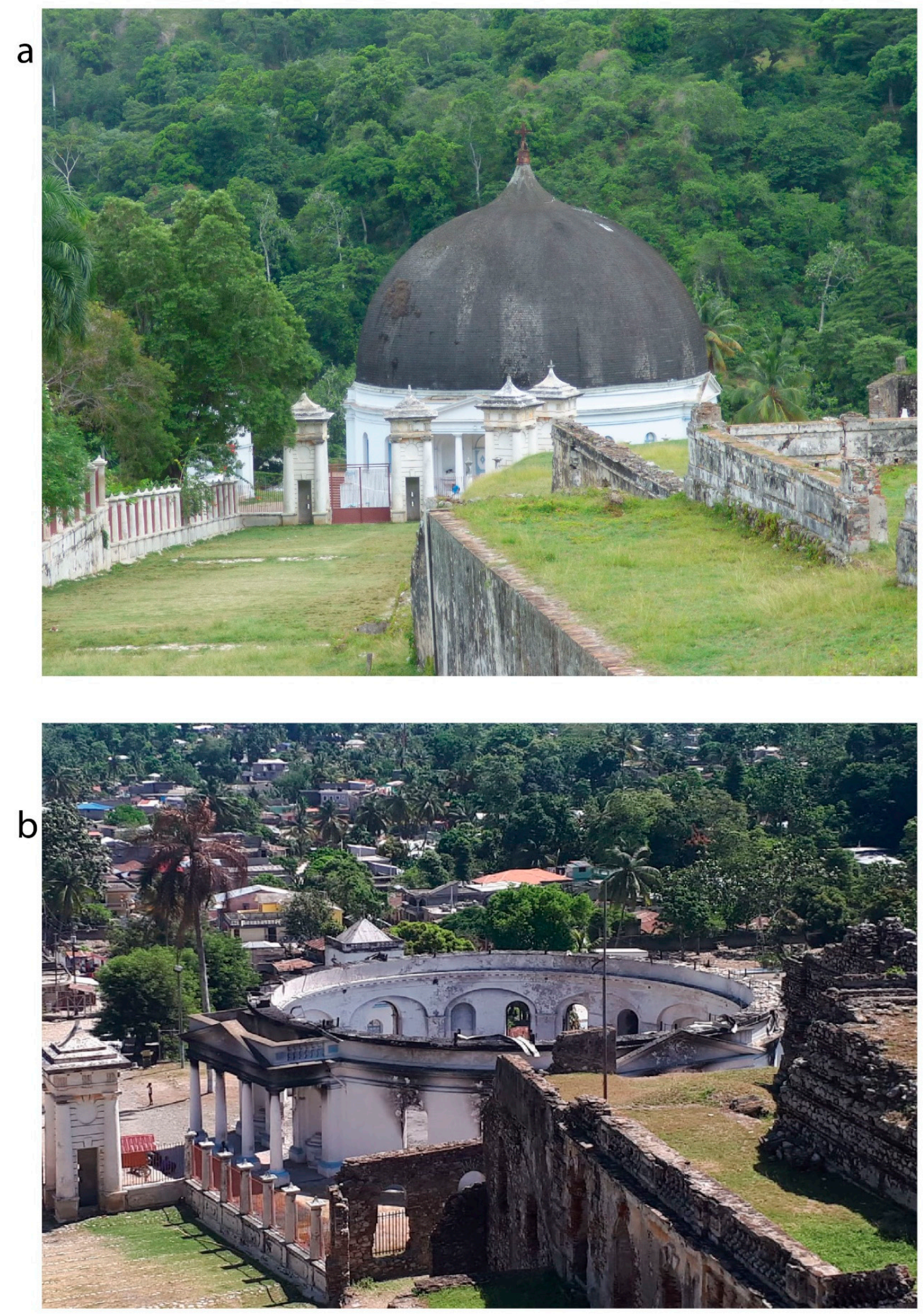

Figure 6. (a) Milot's Church dome before fire; (b) Church after fire (April 2020).

\section{Public Institutions and Archaeological Heritage}

Protecting cultural heritage was not an immediate focus of the Haitian leaders after independence. Any interest related to heritage was part of the fundamental policy of the nation. The notion of culture became a concern around 50 years after independence when the presidential decree published in 1860, 
under the government of Nicolas Guillaume Fabre Geffrard, created the cultural institution, Dépôt Général des Archives d'Haïti, to house the archives of the Haitian state [56] (p. 121).

Haiti waited more than a century after its freedom for "a timid attempt to raise public awareness concerning the need to set up a dedicated place of conservation of cultural goods which are a great part of the public domain [46] (p. 48). A decree was signed on July 26, 1927, by President Louis Borno, to preserve and protect the cultural heritage in Haiti. Article 2 of this law explained that "the public domain is inalienable and imprescriptible and is composed of all things which, without belonging to anyone, are, by 'common enjoyment,' assigned to the service of society in general" [120]. This first law was characterized by limited content, asserting the immovable properties and elements of the natural environment as the public domain. One of the weaknesses of this law concerns the absence of movable heritage and a transparent approach and strategies related to the classification of the Haitian cultural heritage. Additionally, the composition of this public domain is identified in a non-exhaustive manner [121] (p. 2).

Laws related to the classification and conservation of Haitian cultural heritage were published later on April 23, 1940 and October 1941. These laws were enacted to manage and preserve "historical monuments, ruins and memories, buildings and movable objects, sites and monuments of an archaeological nature, historical and artistic or other public interest [121] (p. 2). They were particularly important, giving archaeological heritage a place in the process of classifying and regulating cultural heritage. As early as the 1930s, intensive archaeological research had already been undertaken by American anthropologists in Haiti parallel to the informal artifacts collecting activities [67,69-71]. The law of 31 April 1940 [122] and the decree-law of 31 October 1941 [123] provided the overall guidelines of the Haitian State's policy concerning the safeguarding of popular cultural wealth [72]. Moreover, these regulations led to the creation of specific institutions to manage, protect, and conserve Haitian cultural heritage; among them, the Bureau d'Ethnologie created in 1941 [123], Institut du Sauvegarde du Patrimoine National Haitien (ISPAN) established in 1979 [124], and the Musée du Pantheon National Haitien (MUPANAH) created in 1983 [125].

The creation of the first official institution to conserve the Haitian artifacts and cultural materials set the ground for Haitian scholars to become involved scientifically in archaeological research and to continue collaboration with international researchers. The Bureau National d'Ethnologie was designed in 1941 to renew interest in archaeology and to save religious objects destined to be destroyed [72]. Its creation was the result of political unrest, social demands, and the quest for national identity. The Bureau's purpose was to provide the country with an institution capable of repairing the affront suffered by Vodou practitioners in Haiti and to educate the Haitian public about native Amerindian cultures [72]. As the institution was given the main task to identify, classify, and conserve any archaeological objects found on Haitian territory, as well as carry out and disseminate research on Haitian culture [123], archaeological heritage became a central concern in Haitian heritage politics. This institution was also a museum and a center for scientific research. It had a critical mission consisting of protecting and investigating archaeological sites, as well as cataloguing, conserving, and valorizing archaeological and anthropological objects, along with the development and transmission of Haitian ethnological, anthropological and archaeological knowledge.

Over time, the Bureau d'Ethnologie, in terms of sustainable archaeological heritage practices, has experienced many relocations, fires, and vandalism [46]. Some years after its creation, political usurpation and control over the institution contributed to the slowdown of its missions and objectives [48] (p. 182). As a result, the primary tasks of the Bureau d'Ethnologie related to archaeological investigations in Haiti were transferred to ISPAN from 1979 to 1984, during archaeological investigations on Puerto Real by the University of Florida researchers [48]. This new institution, ISPAN, created in 1979, aims to "inventory, intervene, promote and propose cultural properties for classification" [121] (pp. 3-4). Immovable heritage became a crucial preoccupation of this institution, especially in classifying many historic buildings since its creation to the present day [126,127]. The Parc Historique became a World Heritage Site under ISPAN's stewardship in 1982. Parallel to ISPAN and the Bureau d'Ethnologie, 
a new public institution, Musée du Panthéon National, was created in October 1982 [125] "to perpetuate and promote the memory of the Founding Fathers of the "Fatherland" and to conserve documents and objects of historical, archaeological, and artistic value" [46] (p. 48). Archaeological heritage was in the hands of more than one institution by the early eighties. In 1984, the government created the Institut National Haïtien de la Culture et des Arts (INHACA), which regrouped and politically controlled the Archives Nationales, Théâtre National, and the Musée du Panthéon National Haïtien (MUPANAH). At this time (1984), the main missions given to the Bureau d'Ethnologie in 1940 were renewed, becoming the Bureau National d'Ethnologie [48] (p. 182). After the Duvalier dictatorship in 1986, the new constitution of 1987 places culture in the center of the new democratic agenda, stipulating in Article 215 that the archaeological heritage is in the public domain. An additional decree of 10 May 1989 created a National Commission of Heritage [128]; however, controversial decisions related to archaeological heritage management have since been undertaken without real transparency, especially with the creation in 1995 of the Office National d'Archéologie Marine (OFNAM) functioning under the supervision of Minister of Planning during Jean Bertrand Aristide's presidency, along with the governmental decision allowing an international company to undertake sub-aquatic archaeological surveys during the transitional government in 2004 [48].

Archaeological site protection is always forgotten in any projects related to land management, road construction, and development projects in Haiti, and are rarely noted in the official discourses. After the 2010 earthquake, an Emergency Red List of Haitian Cultural Objects at Risk [129] had been designated by ICOM as an ideal step in the process of combating the illicit trafficking of Haitian cultural heritage. That, added to the efforts of national and international "first aiders," helped to recover the damaged cultural heritage during this emergency $[130,131]$. Through a volume published in the same year by Museum International titled "Haitian Cultural Heritage and Reconstruction," the Haitian experts used their voices for cultural heritage's role in the rebuilding process of Haiti [53,132-134]. In this volume, Wilfrid Bertrand [132] (p. 35) mentioned that "long-term solutions are needed, including restoring, classifying, and recording all the items" of the Haitian cultural heritage. Ironically, any database and archaeological inventories of collections have been created after the 2010 cataclysm to evaluate the loss.

Haiti contains mainly two public institutional spaces dedicated to preserving movable archaeological heritage, the Bureau National d'Ethnologie and the Musée du Panthéon National Haiitien (MUPANAH). Despite their given roles by official decrees, both are remarkably deficient in conserving the archaeological objects of the country, as neither of them has adopted the basic norms of archaeological conservation nor are they equipped with adequate rooms for the scientific study of objects. Bertrand designated 2010's case as new opportunities, but the importance of archaeological heritage was a neglected component in the Actes des Assises de la Culture [135], organized by the Ministry of Culture, one year after the earthquake in 2011. Along with forgotten places in the cultural policy agenda, many Amerindian artifacts that had been recovered from past excavations and investigations display a poor state of conservation in the museum spaces. The problem of inadequate storage space and poor cataloguing constitute significant factors that critically impact the conservation and preservation of archaeological objects $[46,49,136]$.

\section{Discussion and Conclusions: Embracing Loss and Planning the Future}

\subsection{Archaeological Heritage and the Politics of Heritage in Haiti}

Haitian official heritage discourses and practices prioritize the preservation and valorization of impressive and emblematic colonial and post-colonial buildings, fortresses and World Heritage sites in Haiti (e.g., Sans-Souci Palace and the Citadelle). The politics of heritage emphasize the potential of such places for promoting tourism development and for glorifying the nation's revolutionary and heroic past. After the fire tore through the church at the World Heritage Site in northern Haiti (April 2020), many sentimental manifestations from many Haitians demonstrated concern for the 
imminent and complete loss of the site. These manifestations have their basis in an official politics of heritage that has been authorized during the last three decades that forefronts historical and aesthetic dimensions of architectural buildings, creating an emotional dimension. The priority given to specific sites in national heritage practices considers a cultural legitimacy that is promoted by the government, international organizations, and technical and intellectual discourses as grand narratives that determine how the past is presented by focusing on the nationalist and emblematic character of historic traces [40]. Michel Rolph-Trouillot [137] warns us against this tendency to silence in official historiography, including Haiti's history of slavery, exploitation, colonial occupations, embargoes, exchanges, and conflicts. He believes that we must combat amnesia to rehabilitate the effective and symbolic values of our heritage.

Thousands of archaeological sites and natural places that reflect this contested Haitian history from the perspective and experience of indigenous populations and enslaved African resistance, for example, are not given much attention. Heritage practices as seen through the lens of identity politics focus on the meaning of the past from a top-down perspective, while the "core communities" living at and with these sites are not engaged as part of the safeguarding process.

Challenges can emerge in the process of safeguarding; for instance, some colonial traces in Haiti carry a painful emotional charge, compared to the valorization of the heroic heritage that expresses national pride. However, the reticence to safeguard these traces may be reconsidered to the extent that some community members consider these places as abandoned sites by heritage institutions that do not give them any vital consideration. In this case, there is no conflict between these institutions and community members about what to keep or destroy because heritage institutions are absent. The discourses and actions of the people living among and with archaeological heritage sites may change. How some people react to archaeological sites may, in some cases, be linked to the way heritage politics are constructed in Haiti; for example, priority is given to a selection of heritage sites that represses the role of museums in providing in-depth knowledge of historical and natural traces [49]. At present, those heritage politics are focused on monuments, thus making it difficult to address even simple questions about the lives of the enslaved Africans who resisted French colonization in the Haitian context. For example, what types of utensils did the enslaved African use to prepare food on colonial plantations during colonization, and what do those food ways suggest about these people's struggles for physical and cultural survival? The answers to such questions lie mostly in the neglected places that are not selected for study or preservation by the authorized heritage practices in Haiti. Some other critical interrogations need to be addressed by scientists and community members for the construction of multiple discourses that are central concerns about the past.

For many years, northern Haiti has experienced notable spotlights that fix on its emblematic buildings at the expense of other cultural components shaping the cultural landscape. Northern Haiti is historically known for being the first place to experience the European footprints (En Bas Saline and Puerto Real), the most suitable agricultural lands during the French colonization and the heart of enslaved African resistance and the Haitian Revolution (Plaine du Nord). However, ironically, there are no public museums in this region that highlight this contested history. Amerindian archaeological and non-monumental sites that constitute the deep Haitian history are not "valued" in the process of creating national identity and patrimony through the preservation and display of monumental historical buildings in the landscape.

Globally, archaeology and heritage practices have been crucial to understand the past and promote cultural identity, historical memory and tourism, and many other elements that the past can shed light on for society. By addressing the conditions of the archaeological practices in Haiti, Beauvoir-Dominique has argued that Haitian archaeology suffers from a lack of progress whose seriousness is due in part to politics and the sometimes conflicting ideals among the public institutions, along with the diminishing role of the Bureau National d'Ethnologie in the protection of archaeological heritage [48] (pp. 181-182). 


\section{2. "Common Enjoyment" of Heritage}

The laws of 1940-1941 represent a significant advance in terms of the legal protection of archaeological heritage in Haiti. The decree of 1927 calls for a "common enjoyment" obviously denied in the society, since, rarely, are schools, students, and other individuals able to enjoy this heritage. The perceptions of heritage can be multiple and contested, and they can come from below with agendas that are different from the official regulations. Naturally, there is no need for legal instruments for anyone from any social or cultural background to enjoy heritage. However, laws can address matters related to how to make it available for everyone without being appropriated by a group to legitimize specific versions of the past. Moreover, laws can give directives of how archaeological objects should be maintained in the society as public domain.

The "common enjoyment" of heritage should prioritize multiple voices that can address questions about why and how this heritage matters. The government created institutions to determine the overall guidelines of the Haitian state's policy for safeguarding cultural heritage. However, beyond current heritage management, cultural heritage often falls victim to more pressing political and economic priorities and is primarily neglected in budget planning. The various forms of deterioration observed on cultural sites and landscapes, which are mainly due to natural disasters, political changes, social movements, environmental damage, uncontrolled occupation of the sites, looting, marginalization of ancestral practices and popular traditions bear witness to this fact. Here, heritage matters must also include a critical aspect related to communities' relations to caves with rock art and riverbed petroglyph sites. For instance, caves with rock art might have been used by Amerindians and Africans as places of resistance against colonial powers during colonial invasions [96]. They played an essential role in shaping the Haitian landscape through different historical scales. Caves have a great spiritual value for Vodou religious practitioners who valorize them in a modern context, revealing a complex dimension which interplays ancient and current uses [97]. The most well-known caves in Haiti experience tourist visits and yearly pilgrimages. In addition, the contemporary uses of these unique places can complicate their protection from specific features of pre-colonial and colonial periods. However, they can offer a better understanding of how they can be preserved with more inclusive plans and strategies for these areas. The tangible aspects of heritage are predominant in Haiti at the expense of the intangible elements. This ambivalence reflects a gap between authorities and the everyday life of the population in terms of safeguarding cultural heritage, the diffusion of which requires a real contribution from the communities. Heritage management requires alternatives to conventional trends that focus on the materiality of objects. The intangible heritage cannot be separated from the tangible. In the Caribbean context $[138,139]$, by studying African diaspora archaeological heritage in Nevis, González-Tennant [140] (pp. 45-46) points out that a "mixed methods approach to heritage that situates intangible heritage (e.g., oral histories) alongside tangible heritage (e.g., archaeology) expands our interpretations of sites and their place in local memory".

Several circumstances are affecting the World Heritage Site in Haiti [119], therefore, this situation calls for a new orientation of the heritage approach. Sometimes, national experts focus on technical assessments, and applying universal already done (déjà fait) guidelines and directives on conservation and preservation to traditional tourism-oriented strategies. We do not consider here the living heritage in the sense of "community participation" in heritage projects for getting an economic benefit or "entrepreneurial inclusion." We highlight that the "core community" has the legitimacy for showcasing its own local narratives, aspirations, and experiences as a crucial part of decision-making about the study, interpretation, or future preservation of sites. Additionally, long-term heritage protection calls for other experts besides technical ones-from ethnology, sociology, and anthropology (for understanding and analyzing immediate social impacts) — who can reveal necessary steps to define long-term strategies for the benefit of cultural heritage in the future.

Beyond controversies about the nation's colonial legacy [141], Haiti's cultural heritage problems are also based on the weakness of legislation and the fragility of public institutions. Doucet argued that due to the "lack of means, the government is also powerless to stop the looting and irremediable 
destruction of Haiti's archaeological heritage (land and sub-aquatic), despite specific legal provisions, unfortunately incomplete" [72] (p. 12). These incomplete legal instruments and the absence of a public policy document on culture and heritage express the manifest inability of successive governments to take effective and sustainable action to safeguard and enhance Haiti's cultural heritage. As a result, the role of "protection" of archaeological sites, which was assigned to public institutions in 1941, has never been fulfilled [72] (p. 12).

The future of Haitian cultural heritage must be a significant concern for the Haitian authorities. In order to be effective, in association with public engagement activities, the fight must also be conducted with ordinary and institutional actors (communities, private sectors, and researchers) working in the field of heritage. However, these practical measures must be done with a transparent and ethical responsibility of actors by taking concerted actions that disadvantage illegal investigations and looting of sites. Heritage must become a priority of the State, to the extent that public institutions concerned with it must be better equipped and provided with solid economical and logistical means to contribute to the sustainable future of heritage. The State must implement a strong public policy for heritage safeguarding by considering training in heritage as a key role in the process of inventories and protection of sites and collections through a long-term agenda.

When there is laxity to maintain practical efforts for the protection of archaeological heritage that can create a veritable process of loss, an integrated approach that emphasizes the "living heritage approach" that gives voices to the "core community" along with scientific expertise (which is not prioritizing a dominant trend) and real governmental action in decision-making should set the ground for better protection of the material past. This path is an essential ingredient for capturing an in-depth understanding of the nation's long-term history (not in the form of archaeological work dictated and manipulated by dominant nationalistic agendas and actuated by official political discourses of the past) and tackling issues that block heritage's role in society. The necessity for a country to maintain its archaeological heritage against deterioration and loss requires attention as a fundamental process of justice to demonstrate engagement with the past in order to retain it for present and future generations.

Author Contributions: J.S.J., M.J., C.L. and J.M. participated in the written production of this paper. All authors have read and agreed to the published version of the manuscript.

Funding: This research has been supported by CaribTrails project (Caribbean Transdisciplinary Research. Archaeology of Indigenous Legacies Spinoza).

Acknowledgments: The authors would like to thank Judith A. Habicht Mauche and Jude Todd for editing the English and for their valuable feedback, and Corinne Hofman for insightful comments on the paper. We acknowledge Bureau National d'Ethnologie for providing an administrative permit to do surveys and people at Fort-Liberté for helping during the fieldwork (2014-2016). We would like to thank Navy Nickson for sharing with us the picture of Milot's Church after the fire (April 2020). We thank the three anonymous reviewers for providing insightful comments on earlier versions of this article.

Conflicts of Interest: The authors declare that they have no conflict of interest.

\section{References}

1. Babelon, J.-P.; Chastel, A. La Notion de Patrimoine; Payot: Paris, France, 2000.

2. Benhamou, F. Économie du Patrimoine Culturel; La Découverte: Paris, France, 2006.

3. Harrison, R. Heritage: Critical Approaches; Routledge: Abingdon, UK, 2012.

4. Poulot, D. Patrimoine et Modernité; L'Harmattan: Paris, France, 1997.

5. Samuels, K.L. Mobilizing Heritage, Anthropological Practice and Transnational Prospects; University Press of Florida: Gainesville, FL, USA, 2018.

6. Di Méo, G. Processus de patrimonialisation et construction des territoires. In Proceedings of the Colloque "Patrimoine et Industrie en Poitou-Charentes: Connaître pour Valoriser", Poitiers-Châtellerault, France, 12-14 September 2007; Geste Éditions: Poitiers-Châtellerault, France, 2007; pp. 87-109.

7. Trabelsi, S. Développement Local et Valorisation du Patrimoine Culturel Fragile: Le Rôle Médiateur des ONG: Cas du Sud-Tunisien; Université Nice Sophia Antipolis: Cote d'Azur, France, 2016. 
8. Davallon, J.; Du patrimoine à la patrimonialisation. Lauret, J.-M., Ed. Available online: http://preac.crdpparis.fr/fileadmin/user_upload/Ressources/2012/1_Jean_Davallon.pdf (accessed on 5 March 2020).

9. Pajard, A.; Ollivier, B. Traces et légitimation du passe: Des objets aux corps. In L'Homme-Trace: Des Traces du Corps au Corps-Trace; Galinon-Melenec, B., Ed.; CNRS Éditions via OpenEdition: Paris, France, 2019; pp. 371-388.

10. Hofman, C.L.; Haviser, J.B. Managing our Past into the Future: Archaeological Heritage Management in the Dutch Caribbean; Sidestone Press: Leiden, The Netherlands, 2015.

11. Jordan, L.-A. Managing built heritage for tourism in Trinidad and Tobago: Challenges and opportunities. J. Herit. Tour. 2013, 8, 49-62. [CrossRef]

12. Siegel, P.E.; Hofman, C.L.; Bérard, B.; Murphy, R.; Hung, J.U.; Rojas, R.V.; White, C. Confronting Caribbean heritage in an archipelago of diversity: Politics, stakeholders, climate change, natural disasters, tourism, and development. J. Field Archaeol. 2013, 38, 376-390. [CrossRef]

13. Siegel, P.E.; Righter, E. Protecting Heritage in the Caribbean; University of Alabama Press: Tuscaloosa, AL, USA, 2011.

14. Boger, R.; Perdikaris, S.; Rivera-Collazo, I. Cultural heritage and local ecological knowledge under threat: Two Caribbean examples from Barbuda and Puerto Rico. J. Anthropol. Archaeol. 2019, 7, 1-14. [CrossRef]

15. Cooper, J.; Peros, M. The archaeology of climate change in the Caribbean. J. Archaeol. Sci. 2010, 37, $1226-1232$. [CrossRef]

16. Douglass, K.; Cooper, J. Archaeology, environmental justice, and climate change on islands of the Caribbean and southwestern Indian Ocean. Proc. Natl. Acad. Sci. USA 2020, 117, 8254-8262. [CrossRef]

17. Dunnavant, J.P.; Flewellen, A.O.; Jones, A.; Odewale, A.; White, W. Assessing Heritage Resources in St. Croix Post-Hurricanes Irma and Maria. Transform. Anthropol. 2018, 26, 157-172. [CrossRef]

18. Ezcurra, P.; Rivera-Collazo, I.C. An assessment of the impacts of climate change on Puerto Rico's Cultural Heritage with a case study on sea-level rise. J. Cult. Herit. 2018, 32, 198-209. [CrossRef]

19. Fitzpatrick, S.M. On the shoals of giants: Natural catastrophes and the overall destruction of the Caribbean's archaeological record. J. Coast. Conserv. 2012, 16, 173-186. [CrossRef]

20. Gould, K.A.; Lewis, T.L. Green Gentrification and Disaster Capitalism in Barbuda: Barbuda has long exemplified an alternative to mainstream tourist development in the Caribbean. After Irma and Maria, that could change. NACLA Rep. Am. 2018, 50, 148-153. [CrossRef]

21. Hall, C.M.; Baird, T.; James, M.; Ram, Y. Climate change and cultural heritage: Conservation and heritage tourism in the Anthropocene. J. Herit. Tour. 2016, 11, 10-24. [CrossRef]

22. Hofman, C.L.; Hoogland, M.L.P. Connecting stakeholders: Collaborative preventive archaeology projects at sites affected by natural and/or human impacts. Caribb. Connect. 2016, 5, 1-31.

23. Scantlebury, M. The impact of climate change on heritage tourism in the Caribbean: A case study from Speightstown, Barbados, West Indies. Int. J. Clim. Chang. Impacts Responses 2009, 1, 37-48. [CrossRef]

24. Scott, D.; Simpson, M.C.; Sim, R. The vulnerability of Caribbean coastal tourism to scenarios of climate change related sea level rise. J. Sustain. Tour. 2012, 20, 883-898. [CrossRef]

25. Stancioff, C.E.; Stojanov, R.; Kelman, I.; Němec, D.; Landa, J.; Tichy, R.; Prochazka, D.; Brown, G.; Hofman, C.L. Local perceptions of climate change impacts in St. Kitts (Caribbean sea) and Malé, Maldives (Indian ocean). Atmosphere 2018, 9, 459. [CrossRef]

26. Hofman, C.L.; Hung, J.U.; Malatesta, E.H.; Jean, J.S.; Sonnemann, T.; Hoogland, M. Indigenous Caribbean perspectives: Archaeologies and legacies of the first colonised region in the New World. Antiquity 2018, 96, 200-216. [CrossRef]

27. Jean, J.S. La Biographie D'un Paysage: Etude sur les Transformations de Longue Durée du Paysage Culturel de la Région de Fort-Liberté, Haïti; Sidestone Press: Leiden, The Netherlands, 2019.

28. Koski-Karell, D. Prehistoric Northem Haïti Settlement in Diacronic Ecological Context. Ph.D. Thesis, Catholic University of America, Washington, DC, USA, 2002.

29. Moore, C.; Tremmel, N. Settlement Patterns in Pre-Columbian Haiti: An Inventory of Archaeological Sites; Bureau National d'Ethnologie: Port-au-Prince, Haiti, 1997.

30. DeSilvey, C.; Harrison, R. Anticipating loss: Rethinking endangerment in heritage futures. Int. J. Herit. Stud. 2020, 26, 1-7. [CrossRef]

31. Korka, E. The Protection of Archaeological Heritage in Times of Economic Crisis; Cambridge Scholars Publishing: Cambridge, UK, 2015. 
32. Gould, P.G. Empowering Communities through Archaeology and Heritage: The Role of Local Governance in Economic Development; Bloomsbury Publishing: London, UK, 2018.

33. Nijkamp, P. Economic valuation of cultural heritage. In The Economics of Uniqueness: Investing in Historic City Cores and Cultural Heritage Assets for Sustainable Development; Licciardi, G., Amirtahmasebi, R., Eds.; World Bank: Washington, DC, USA, 2012; pp. 75-103.

34. Throsby, D. Heritage economics: A conceptual framework. In The Economics of Uniqueness: Investing in Historic City Cores and Cultural Heritage Assets for Sustainable Development; Licciardi, G., Amirtahmasebi, R., Eds.; World Bank: Washington, DC, USA, 2012; pp. 45-74.

35. ICOMOS. Burra Charter (Fourth Version): The Australia ICOMOS Charter for the Conservation of Places of Cultural Significance; ICOMOS: Charenton-le-Pont, France, 1999.

36. Poulios, I. Moving Beyond a Values-Based Approach to Heritage Conservation. Conserv. Manag. Archaeol. Sites 2010, 12, 170-185. [CrossRef]

37. Poulios, I. The Past in the Present: A Living Heritage Approach-Meteora, Greece; Ubiquity Press: London, UK, 2014.

38. Robertson, I.J.M. Heritage from Below; Ashgate Publishing, Ltd.: Farnham, UK, 2012.

39. Smith, C.; Wobst, H.M. The next step: An archaeology for social justice. In Indigenous Archaeologies: Decolonising Theory and Practice; Smith, C., Wobst, H.M., Eds.; Routledge: Abington, UK, 2004; p. 369.

40. Smith, L. Uses of Heritage; Routledge: London, UK, 2006.

41. Waterton, E. Politics, Policy and the Discourses of Heritage in Britain; Palgrave Macmillan: New York, NY, USA, 2010.

42. Watson, S.; Waterton, E. Heritage and community engagement. Int. J. Herit. Stud. 2010, 16, 1-3. [CrossRef]

43. Rizvi, U.Z. Archaeological futures and the postcolonial critique. In Archaeology and the Postcolonial Critique; Leibmann, M., Rizvi, U.Z., Eds.; AltaMira Press: Lanham, MD, USA, 2008; pp. 197-203.

44. Lenik, S. Community engagement and heritage tourism at Geneva Estate, Dominica. J. Herit. Tour. 2013, 8, 9-19. [CrossRef]

45. Sankatsing, N.T.; Hofman, C.L. Engaging Caribbean island communities with indigenous heritage and archaeology research. JCOM J. Sci. Commun. 2018, 17, 10. [CrossRef]

46. Vendryes, M.-L. Haiti, Museums and Public Collections: Their History and Development after 1804. In Plantation to Nation: Caribbean Museums and National Identity; Cummins, A., Farmer, K., Russell, R., Galla, A., Eds.; Common Ground: Champaign, IL, USA, 2013; pp. 47-56.

47. McDowell, S. Heritage, memory and identity. In The Ashgate Research Companion to Heritage and Identity; Graham, B., Howard, P., Eds.; Ashgate Publishing: Farnham, UK, 2016; pp. 37-54.

48. Beauvoir-Dominique, R. Puerto Real: Défis nationaux et internationaux de l'archéologie haïtienne. In Caribbean Archaeology and World Heritage Convention; Sanz, N., Ed.; World Heritage Papers 14; Unesco: Paris, France, 2005; pp. 178-184.

49. Joseph, M. Mise en Scène des Collections Archéologiques en Haïti, Le Cas du Musée du Panthéon National Haïtien et du Musée Ethnographique du Bureau National Ethnologie. Masrer's Thesis, Université d' Etat d' Haiti, Port-au-Prince, Haiti, 2017.

50. Demesvar, K. Interprétation et Mise en Valeur du Patrimoine Naturel et Culturel, Matériel et Immatériel Dans les Parc Nationaux-Cas du Parc National Historique: Citadelle, Sans-Souci, Ramiers de la République d'Haïti. Ph.D. Thesis, Université Laval, Laval, QC, Canada, 2015.

51. Geller, P.L.; Marcelin, L.H. In the shadow of the Citadel: Haitian national patrimony and vernacular concerns. J. Soc. Archaeol. 2020, 20, 49-73. [CrossRef]

52. Dautruche, J.R. Tourisme culturel et patrimoine remodelé: Dynamique de mise en valeur du patrimoine culturel immatériel en Haïti. Ethnologies 2013, 35, 145-161. [CrossRef]

53. Turgeon, L.; Divers, M. Intangible Cultural Heritage in the Rebuilding of Jacmel and Haiti Jakmèl kenbe la, se fòs peyi a!1. Mus. Int. 2010, 62, 106-115. [CrossRef]

54. Dorcé, R. Participation communautaire, patrimoine et tourisme en Haïti: Le cas du parc de Martissant. Rabaska Revue d'ethnologie de l'Amérique Française 2019, 17, 121-132. [CrossRef]

55. Régulus, S. Transmission de la Prêtrise Vodou: Devenir Ougan ou Manbo en Haïti. Ph.D. Thesis, Université Laval, Laval, QC, Canada, 2012.

56. Augustin, J.R. Mémoire de L'esclavage en Haïti. Entrecroisement des Mémoires et Enjeux de la Patrimonialisation. Ph.D. Thesis, Université Laval, Laval, QC, Canada, 2016. 
57. Charlevoix, P.-F.-X. Histoire de L'isle Espagnole ou de S. Domingue Écrite Particulièrement sur des Mémoires Manuscrits du P. Jean-Baptiste le Pers, Jésuite, Missionnaire à Saint-Domingue, et sur les Pièces Originales, qui se Conservent au Dépôt de la Marine; Jacques Gérin: Paris, France, 1730; Volume 2.

58. Delpuech, A. Sur la constitution des Naturels du pays: Archaeology in French Saint-Domingue in the Eighteenth Century. In Proceedings of the 25th International Congress for Caribbean Archaeology, San Juan, Puerto Rico, 15-21 July 2013; pp. 582-607.

59. Moreau de Saint-Méry, L.-É. Description Topographique, Physique, Civile, Politique et Historique de la Partie Française de L'isle Saint-Domingue; Chez Dupont: Paris, France, 1797; Volume 1.

60. Alberti Bosch, N. Alfaneria Indigena, Antillas y Centro America, Isla de Hä̈ti o Quisquella; Paufilia: Santo Domingo, Dominican Republic, 1921.

61. Fewkes, J.W. A Prehistoric Island Culture Area of America; US Government Printing Office: Washington, DC, USA, 1922.

62. Piacentini, R. A propos de fragments de poteries Indiennes. Bull. Seminaire-College St. Martial 1914, 1, 234-239.

63. Reynoso, A. Notas Acerca del Cultivo en Camellones: Agricultura de los Indígenas de Cuba y Haití; E. Leroux.: Paris, France, 1881.

64. Safford, W.E. Identity of cohoba, the narcotic snuff of ancient Haiti. J. Wash. Acad. Sci. 1916, 6, 547-562.

65. Pettigrew, R.L. The Story of Fort Liberty and the Dauphin Plantation; Cavalier Press: Richmond, VA, USA, 1958.

66. Krieger, H. Cultural Sequence in Haiti. Exploration and Field-Work of Smithson. Inst. 1931 1932, 3134, $113-123$.

67. Rainey, F.G. A new prehistoric culture in Haiti. Proc. Natl. Acad. Sci. USA 1936, 22, 4. [CrossRef]

68. Boggs, S.H. Note on excavation in northern Haiti. Am. Antiq. 1940, 3, 258.

69. Rainey, F.G. Excavations in the Ft. Liberté Region., Haiti; Yale University Press: New Haven, CT, USA, 1941.

70. Rouse, I.G. Prehistory in Haiti: A Study in Method; Yale Publications in Anthropology: New Haven, CT, USA, 1939.

71. Rouse, I.G. Culture of Fort Liberte Region., Haiti; Yale University Press: New Haven, CT, USA, 1941; Volume 24.

72. Charlier-Doucet, R. Anthropologie, politique et engagement social. L'expérience du Bureau d'ethnologie d'Haïti. Gradhiva Rev. D'anthropol. D'hist. Arts 2005, 1, 109-125.

73. Viré, A. La préhistoire en Haïti. Bull. Soc. Préhist. Fr. 1940, 37, 108-137. [CrossRef]

74. Aubourg, M. Les recherches archéologiques de M. Herber Krieger dans le nord d' Haiti. Bull. Bur. D'Ethnol. 1947, 3, 41-49.

75. Aubourg, M. Haiti Prehistorique: Memoire sur les Cultures Précolombiennes Ciboney et Taino; Editions Panorama: Port-au-Prince, Haiti, 1951.

76. Barker, P. Les Cultures Cadet et Manigat, Emplacements de Villages Précolombiens Dans le Nord-Ouest D' Haiti; Imprimerie de L'Etat: Port-au-Prince, Haiti, 1961; Volume 26, pp. 1-70.

77. Bastien, R. Archéologie de la Baie de Port-au-Prince. Bull. Bur. D’Ethnol. 1944, 3, 33-38.

78. Fisher, K. Une tête anthropomorphique en pierre de L'ile a Cabrit. Bull. Bur. D'Ethnol. 1944, 3, 39.

79. Fisher, K. La Culture Préhistorique d' Haiti (Ciboneys). Bull. Bur. D'Ethnol. Répub. D'Haiti 1947, 2, 22-26.

80. Roumain, J. L'outillage lithique des Ciboney d'Haiti. Bull. Bur. D'Ethnol. Répub. D'Haiti 1943, 2, $22-27$.

81. Roumain, J. Site de Source Matelas-Cabaret. Bull. Bur. D'Ethnol. 1943, 3, 25-26.

82. Hodges, W. Puerto Real and Limbé: An Analysis; Musée Guahaba: Limbé, Haiti, 1979.

83. Hodges, W. Quelques reflexions sur la Roche Tempée. Bull. Bur. Natl. D'Ethnol. 1984, 1, 39-47.

84. Hodges, W. The Search for la Navidad, Explorations at En Bas Saline, 1983; Musée Guahaba: Limbé, Haiti, 1984.

85. Davilia, O. Analysis of the Lithic Materials of the Savanne Carré No. 2 Site, Ft. Liberté Region in Haiti. Boletín de Museo del Hombre Dominicana 1978, 7, 201-226.

86. Keegan, W.F. Archaeological excavations on Ile a Rat, Haiti: Avoid the Oid. In Proceedings of the 18th International Congress for Caribbean Archaeology, St. George, Grenada, 11-17 July; Richard, G., Ed.; Basse-Terre: L'Association Internationale d'Archéologie de la Caraïbe: St. George, Grenada, 2001; pp. 233-239.

87. Ortega, E.; Guerrero, J. El fechado del sito Mellacoide Bois Charite, Haiti. Boletin del Museo del Homre 1982, 17, 29-53.

88. Rainey, F.G.; Aguilu, O. Bois Noeuf: The Archaeological View from West. Central Haiti; Bureau National D'Ethnologie: Port-au-Prince, Haiti, 1983; p. 89.

89. Rouse, I. The Olsen collection from Ile a Vache, Haiti. Fla. Anthropol. 1982, 35, 169-185. 
90. Rouse, I.; Moore, C. Cultural sequence in southwestern Haiti. Bull. Bur. Natl. D'Ethnol. 1984, 1, 25-38.

91. Jagou, S. Cinq ans d'explorations en Haïti. Spelunca 2014, 136, 1-5.

92. Kambesis, P.N.; Lace, M.J.; Despain, J.; Goodbar, J. Assessment of Grotte Marie-Jeanne, Port-à-Piment, Republique D'Haiti; Delivered to Ministère du Tourisme: Port-au-Prince, Haïti, 2010.

93. Lace, M.J. Advances in the Exploration and Management of Coastal Karst in the Caribbean. In Environmental Management and Governance: Advances in Coastal and Marin; Finkl, C.W., Makowski, C., Eds.; Springer: Cham, Switzerland; New York, NY, USA, 2015; pp. 143-172.

94. Testa, O.; Devillers, C. Expédition Spéléologique en Haïti Ayiti Toma. 2009. Available online: https: //rapports-expeditions.ffspeleo.fr/2009-023.pdf (accessed on 10 April 2020).

95. Beauvoir-Dominique, R. Rock Art of Haiti. In Rock Art of Latin America and the Caribbean: Thematic Studies; ICOMOS, Ed.; ICOMOS: Paris, France, 2006; pp. 75-78.

96. Beauvoir-Dominique, R. The rock images of Haití. A living heritage. In Rock Art of the Caribbean; Hayward, M., Atkinson, L.G., Cinquino, M.A., Eds.; University of Alabama Press: Tuscaloosa, AL, USA, 2009; pp. 78-89.

97. Salgado, A. Hauts-Lieux Sacrés Dans le Sous-Sol D'Haïti; Ateliers Fardin: Port-au-Prince, Haïti, 1980; p. 243.

98. Deagan, K. Initial encounters: Arawak responses to European contact at the En Bas Saline site, Haiti. In Proceedings of the First San Salvador Conference, San Salvador, The Bahamas, 3 October-5 November 1986; Gerace, D.T., Ed.; College Center of the Finger Lakes: San Salvador, The Bahamas, 1987; pp. 341-359.

99. Deagan, K. A la recherche de la Nativité. Bull. Natl. D'Ethnol. 1992, 47-63.

100. Ewen, C.R. From Spaniard to Creole: The Archaeology of Cultural Formation at Puerto Real, Haiti; University of Alabama Press: Tuscaloosa, AL, USA, 1991.

101. Fairbanks, C.; Marrinan, R. The Puerto Real Project, Haiti. In Proceedings of the 9th International Congress for the Study of Precolumbian Cultures of the Lesser Antilles, Santo-Domingo, Dominican Republic, 2-8 August 1981; Centre de Recherches Caraibes, Université de Montréal: Montréal, Canana, 1983; pp. 409-417.

102. LeFebvre, M.J. Animals, Food, and Social Life Among the Pre-Columbian Taino of En Bas Saline, Hispaniola. PhD. Thesis, University of Florida, Gainesville, FL, USA, 2015.

103. McEwan, B.G. Domestic Adaptation at Puerto Real, Haiti. Hist. Archaeol. 1986, 20, 44-49. [CrossRef]

104. Reitz, E.J. Vertebrate Fauna from Locus 39, Puerto Real, Haiti. J. Field Archaeol. 1986, 13, 317-328.

105. Shapiro, G. A soil resistivity survey of 16th century Puerto Real, Haiti. J. Field Archaeol. 1984, 11, 101-110.

106. Williams, M. Sub-surface patterning at 16th century Spanish Puerto Real, Haiti. J. Field Archaeol. 1986, 13, 283-296.

107. Willis, R. Empire and Architecture at 16th Century Puerto Real, Hispaniola. Ph.D. Thesis, University of Florida, Gainesville, FL, USA, 1984.

108. Deagan, K. Puerto Real: The Archaeology of a Sixteenth Century Spanish Town in Hispaniola; University Press of Florida: Gainesville, FL, USA, 1995.

109. Le Bulletin de l'Ipan. Available online: Ispan.gouv.ht:https://ispan.gouv.ht/?page_id=442 (accessed on 10 May 2020).

110. Cauna, J. Patrimoine et mémoire de l'esclavage en Haïti: Les vestiges de la société d'habitation coloniale. In Situ 2013. [CrossRef]

111. Lerebours, M.P. L'habitation Sucrière Dominguoise et Vestiges D'habitations Sucrières Dans la Région de Port-au-Prince; Éditions Presses Nationales Haïti: Port-au-Prince, Haiti, 2006.

112. Monroe, J.C. New Light from Haiti's Royal Past Recent Archaeological Excavations in the Palace of Sans-Souci, Milot. J. Haitian Stud. 2017, 23, 5-31. [CrossRef]

113. Sonnemann, T.; Jean, J.S. Living on Heritage-Amerindian Presence in Haiti. (Video). 2016. Available online: https://www.youtube.com/watch?v=X-VIK6oLewk\&t=7s (accessed on 10 March 2020).

114. Guzman, J. Environmental Impact Assessment, SISALCO 4.000 ha Pilot Sisal Plantation Project in North-East Haiti; Ministry of Agriculture, Natural Resources, and Rural Development: Port-au-Prince, Haiti; Inter American Development Bank: New York, NY, USA, 2016; pp. 1-218.

115. Voltaire, L. Etude D'impact Social du Projet Proposé de Développement du Sisal Dans la Région Nord-Est D’Haïti; Delivered to Ministère de L'Agriculture, des Ressources Naturelles et du Développement Rural (MARNDR): Port-au-Prince, Haiti, 2016.

116. Ménanteau, L.; Vanney, J.-R. Atlas Côtier du Nord-Est D'Haïti: Environment et Patrimoine Culturel de la Région de Fort-Liberté; Ministère de la Culture: Port-au-Prince, Haiti, 1997. 
117. Ceci.ca.fr. Available online: https://ceci.ca/fr/nouvelles-evenements/rapport-dinventaire-des-ressourcestouristiques-du-nord-et-du-nord-est-projet-dappui-au-developpement-touristique-de-la-region-norddhaiti (accessed on 10 May 2020).

118. Beauvoir-Dominique, R. Puerto-Real: Pour une Mise en Valeur Nationale, Caraïbéenne et Mondiale; Projet Route 2004: Port-au-Prince, Haiti, 1996.

119. ISPAN. Le Parc National Historique Citadelle, Sans-Souci, Ramiers: Etat de Conservation; Institut de Sauvegarde du Patrimoine National: Port-au-Prince, Haïti, 2010; pp. 1-22.

120. Loi 27 Juillet 1927. Règlementant le service domanial. In Bulletin des lois et actes 1927; Edition Officielle, Ed.; Imprimerie de l'Etat: Port-au-Prince, Haïti, 1928; pp. 183-189.

121. ISPAN. Lois, décrets et sauvegarde du patrimoine. Bulletin de de l'Ispan 2011, 27, 1-6.

122. Le Moniteur. Loi 1940 classant comme monuments historiques les immeubles dont la conservation présente un intérêt public. Le Moniteur. Journal Officiel de la République d'Haiti 1940, 34, 268-272.

123. Le Moniteur. Décret-loi du 31 octobre 1941. La Création du Bureau d’Ethnologie. Le Moniteur. Journal Officiel de la Républiqued'Haiti 1941, 94, 770-771.

124. Le Moniteur. Decret du 5 avril 1979. L'Institut de Sauvegarde du Patrimoine National (ISPAN). Le Moniteur. Journal Officiel de la République d'Haiti 1979, 32, 81-82.

125. Le Moniteur. Jeudi 21 octobre 1982. Création du Musée du Panthéon National haïtien (MUPANAH). Le Moniteur. Journal Officiel de la République d'Haiti 1982, 73, 63-67.

126. ISPAN. 200 Monuments et Sites D'Haïti a Haute Valeur Culturelle, Historique ou Architecturale; Henri Deschamps: Port-au-Prince, Haiti, 2014.

127. Rocourt, M. La Citadelle Henry; Global Project Service Inc.: Quoquina, FL, USA, 2009.

128. Le Moniteur. Décret du 10 mai 1989. La Commission Nationale du Patrimoine. Le Moniteur. Journal. Officiel de la Républiqued'Haiti 1989, 55, 956-960.

129. Icom. Available online: https://icom.museum/en/ressource/emergency-red-list-of-haitian-cultural-objectsat-risk/ (accessed on 10 March 2020).

130. Stolk, D. Contributing to Haiti's Recovery through Cultural Emergency Response. Mus. Int. 2010, 62, 82-89. [CrossRef]

131. Tandon, A. First Aid for Haiti's Cultural Heritage. Mus. Int. 2010, 62, 65-72. [CrossRef]

132. Bertrand, W. Haiti: Threatened Cultural Heritage and New Opportunities. Mus. Int. 2010, 62, 34-38. [CrossRef]

133. Elie, D. The Role of ISPAN in the Restoration of Memory. Mus. Int. 2010, 62, 22-25. [CrossRef]

134. Julien, O.J. Port-au-Prince: Historical Memory as a Fundamental Parameter in Town Planning. Mus. Int. 2010, 62, 26-33. [CrossRef]

135. MCC. Actes des Assises Nationales de la Culture; Ministère de la Culture et de la Communication (MCC): Port-au-Prince, Haiti, 2011.

136. Vendryes, M.-L. Des fragments et des traces. Lett. L'OCIM 2003, 88, 18-23.

137. Trouillot, M.-R. Silencing the Past: Power and the Production of History; Beacon Press: Boston, MA, USA, 1995.

138. Pesoutova, J. Indigenous Ancestors and Healing Landscapes: Cultural Memory and Intercultural Communication in the Dominican Republic and Cuba; Sidstone Press: Leiden, The Netherlands, 2019.

139. Pesoutova, J. Paisajes curativos dominicanos como expresión de la memoria cultural: Una reflexión sobre sus rizomas. Cienc. Soc. 2019, 44, 51-68. [CrossRef]

140. González-Tennant, E. The "Color" of Heritage: Decolonizing Collaborative Archaeology in the Caribbean. J. Afr. Diaspora Archaeol. Herit. 2014, 3, 26-50. [CrossRef]

141. Michel, J. Les enjeux de la patrimonialisation du parc historique de la canne-à-sucre en Haïti. Articulo-J. Urban Res. 2014. [CrossRef]

(C) 2020 by the authors. Licensee MDPI, Basel, Switzerland. This article is an open access article distributed under the terms and conditions of the Creative Commons Attribution (CC BY) license (http://creativecommons.org/licenses/by/4.0/). 